\title{
Article/Artigo
}

\section{Clinical and laboratory findings in patients with dengue associated with hepatopathy}

\section{Achados clínicos e laboratoriais em pacientes com dengue associada à hepatopatia}

\author{
Delso do Nascimento ${ }^{1}$, Ana Rita Coimbra Motta de Castro ${ }^{2}$, Íris Bucker Froes ${ }^{1}$, Gláucia Bigaton ${ }^{1}$, Éveny Cristine \\ Luna de Oliveira ${ }^{1}$, Márcia Ferrario Janine Dal Fabbro ${ }^{3}$, Rivaldo Venâncio da Cunha ${ }^{1}$ and Izaias Pereira da Costa ${ }^{1}$
}

\begin{abstract}
Introduction: Hepatic disorders caused by dengue infection may progress to severe manifestations, including mortality and morbidity. Cytokines are involved in it, such as the migration inhibitory factor of macrophages (MIF), tumor necrosis factor (TNF), natural killer cells (NK), B lymphocytes, and macrophages. Methods: This study was carried out from January to April 2007 at a public hospital from the Federal University of Mato Grosso do Sul, Campo Grande, Brazil. Sixty-eight patients were studied concerning hepatic alterations, with 56 reported having classic dengue, 6 with hemorrhagic dengue grade I, and 6 with hemorrhagic dengue grade II. Results: Among the 56 with classic dengue, $83.3 \%$ had aspartate aminotransferase (AST) alterations, and 69.6\% had altered alanine aminotransferase (ALT). For those with hemorrhagic dengue grade I, $100 \%$ had AST alterations, and $83.3 \%$ had altered ALT. All the patients with hemorrhagic dengue grade II had AST and ALT alterations. AST variations reached 22.0 and 907.0, with an average value of 164.6. For ALT, we found variations between 25.0 and 867.0 , with an average value of 166.07 . There had been statistical significance between dengue clinical shapes and hepatic function markers. Conclusions: We conclude that the infection was predominant in adults, females, and in those with low income and education. The liver enzymes were of larger amount in hemorrhagic dengue, but there was weak statistical evidence of the clinical manifestations and transaminases. Major signs and clinical symptoms were fever, headache, myalgia, arthralgia, weakness, severe pain behind the eyes, and rashes.
\end{abstract}

Keywords: Dengue. Hemorrhagic dengue. Hepatitis.

\section{RESUMO}

Introdução: Afecções hepáticas causadas pela infecção da dengue podem evoluir para quadro grave, incluindo mortalidade e morbidade. $\mathrm{O}$ mecanismo de lesão do fígado está relacionado com a exacerbação da resposta imune. As citocinas estão envolvidas nele como fator inibidor da migração de macrófagos (MIF), fator de necrose tumoral (TNF), células natural killer (NK), B linfócitos e macrófagos. Métodos: Este estudo foi realizado em um hospital público da Universidade Federal do Mato Grosso do Sul. As alterações hepáticas pelo dengue podem evoluir com quadros graves e potencialmente letais. Foram avaliados exames de 68 pacientes atendidos e confirmados com dengue, onde 56 foram classificados como dengue clássico, seis, como dengue hemorrágico grau I e seis como dengue hemorrágico grau II. Resultados: Do dengue clássico, 83,3\% tiveram alterações de aspartato aminotransferase (AST) e 69,6\% alterações para alanino aminotransferase (ALT). No dengue hemorrágico grau I, AST elevou-se $100 \%$ e para ALT $83,3 \%$. No dengue hemorrágico grau II observou-se $100 \%$ de alterações tanto para AST, quanto para ALT. A variação de AST ficou entre 22,0 e 907,0 com média de 164,6. A alanino aminotransferase variou entre 25,0 e 867,0 com média de 166,07 . Houve significância entre formas clínicas do dengue e marcadores de função hepática. Conclusões: Conclui-se que a infecção predominou em adultos do sexo feminino, de baixa renda e escolaridade. As enzimas hepáticas elevam-se mais no dengue hemorrágico, fraca evidência estatística entre as manifestações clínicas e as transaminases. Os mais prevalentes sinais/sintomas clínicos foram febre, cefaléia, mialgia, artralgia, fraqueza, dor retrorbitária e exantema.

Palavras-chaves: Dengue. Dengue hemorrágico. Hepatite.

1. Programa de Pós-Graduação em Doenças Infecciosas e Parasitárias, Universidade Federal de Mato Grosso do Sul, Campo Grande, MS. 2. Laboratório de Imunologia Clínica, Departamento de Farmácia e Bioquímica, Centro de Ciências Biológicas e da Saúde, Universidade Federal de Mato Grosso do Sul, Campo Grande, MS. 3. Centro de Doenças Infecto Parasitárias, Secretaria de Saúde, Prefeitura de Campo Grande, Campo Grande, MS.

Address to: Dr. Delso do Nascimento. R. Antônio Alves Sette 407, Bairro Maria Aparecida Pedrossian, 79044-300 Campo Grande, MS, Brasil.

Phone: 5567 9956-2682

e-mail: delso_nascimento@hotmail.com

Received in $07 / 01 / 2010$

Accepted in 17/05/2011

\section{INTRODUCTION}

Dengue is an acute febrile viral disease of short duration, but nowadays, it is considered reappearing and is distributed on continental proportions. It is caused by an arbovirus, Flaviviridae family, Flavivirus gender, divided into four serotypes: DENV-1, DENV-2, DENV-3, and DENV-4. Man is the only infection host, but there are the wild cycles that keep the viral circulation ${ }^{1,2}$. The disease is transmitted through Aedes gender mosquito bite, with Aedes aegipty being the main vector, which has strong ability to adapt to the peridomiciliar environment ${ }^{3,4}$.

There is a wide viral circulation in Brazil of three serotypes (DENV-1, 2, and 3), triggering the expansion of the epidemic ${ }^{5,6}$. Currently, all Brazilian states have detected the presence of dengue virus, with some imported cases as in State of Santa Catarina?.

DENV-1 was isolated in Mato Grosso do Sul in 1987, and the first epidemic occurred in 1990 with 9,700 cases reported and an incidence rate of 1,470 cases per 100,000 inhabitants ${ }^{8}$. In 1996, there was the introduction of DENV-2 with another epidemic, and in 2002, the introduction of DENV-3 led to an incidence rate of 1,920 cases per 100,000 inhabitants in another epidemic, on the same year?.

Dengue does not usually evolve seriously in most cases, but the disease may present atypical clinical manifestations ${ }^{10,11}$. Hepatic involvement is one of the forms of these events.

The main objective of this work is to describe liver alterations resulting from the infection by dengue virus, which is also described as unusual, and to check possible relations with clinical manifestations.

\section{METHODS}

This is a descriptive study. Data were collected from secondary sources through the analyses of medical records, from the database of the Day-public Hospital Professor Esterina Corsini (HDEC) of Mato Grosso do SulFederal University (UFMS) referring to the epidemic cases that had occurred from January to April 2007. 
Five hundred and thirteen medical records of patients who were examined with suspected dengue at the hospital during the epidemic period were analyzed. Statistical analysis was performed using Epi-Info (version 3.5.2). Information regarding the serological test results, clinical examinations, and laboratory tests (biochemistry) were extracted from the medical records, and the information were recorded in a form designed for the research.

The trial included all the medical records of the patients who fulfilled the clinical requirements with the signs and symptoms of dengue (fever, headache, myalgia, prostration, severe pain behind the eyes, arthralgia, and rashes) determined by the World Health Organization in 2005 and the following laboratory criteria: those individuals with positive serology for enzyme method ELISA capture of IgM capture (Panbio Diagnostics kit, Australian), negative serology for B hepatitis and C hepatitis (Bio-Rad Laboratories kits), aspartate aminotransferase (AST) and alanine aminotransferase (ALT), gamma glutamyl transferase (GGT), alkaline phosphatase (AP), total protein (TP), and albumin (ALB) on at least one collection. The biochemical tests were carried out on automated Dimension RXL equipment, and reagents from Labtest Diagnostic SA were used. All values above normality for liver enzymes $([\mathrm{AST}>37 \mathrm{U} / \mathrm{I}, \mathrm{ALT}>65 \mathrm{U} / \mathrm{I}, \mathrm{GGT}>182 \mathrm{U} / \mathrm{I}, \mathrm{AP}>136 \mathrm{U} / \mathrm{I}]$ and $[\mathrm{TP}<6.4 \mathrm{U} / \mathrm{I}, \mathrm{ALB}<3.4 \mathrm{U} / \mathrm{I}])$ were considered altered; the reference values on International Units $(\mathrm{U} / \mathrm{I})$ were adopted at the university hospital of UFMS.

The criteria for exclusion were determined: information gaps referring to the studied variables, acute infectious or chronic comorbidities, and those taking medications that are potentially hepatotoxic.

\section{Ethical considerations}

As it is a research with secondary data collection, the preparation is dispensed as a term of informed consent, and a waiver request was sent to the ethics committee of the Federal University of Mato Grosso do Sul, Campo Grande, Brazil. In compliance with the recommended resolution 196/96, an associated term commitment to the use of information was obtained from medical records as well as an authorization to access the records.

\section{RESULTS}

\section{Serology results}

All the 68 patients indicated positive serology for dengue by IgMELISA capture; of that total, $85.3 \%$ (58/68) did not have confirmed dengue before or did not have signs/typical symptoms of the illness. All of them were submitted to the serological markers detection for hepatitis B (HBsAg and anti-HBc IgM and IgG) and for hepatitis C by anti-HCV detection.

\section{Clinical manifestations presented}

Wide variations on signs and symptoms were observed on clinical manifestations; they were obtained during the appointment or during patient hospitalization. The most common symptoms observed in at least $60 \%$ of the patients were fever, headache, myalgia, nausea, and vomiting (Table 1).

\section{Biochemical changes}

The biochemical changes observed on these patients were of significant values (Table 2). From the 68 patients, $83.8 \%$ (57) presented values above normal for AST, and 73.5\% (50) reached
TABLE 1 - Percentage of patients admitted at The Day-Hospital Esterina Corsini from January to April 2007 according to observed signs and symptoms.

\begin{tabular}{|c|c|c|c|c|c|c|}
\hline \multirow[b]{2}{*}{ Signs and symptoms } & \multicolumn{2}{|c|}{ Yes } & \multicolumn{2}{|c|}{ No } & \multicolumn{2}{|c|}{ Unknown } \\
\hline & $\mathbf{n}$ & $\%$ & $\mathbf{n}$ & $\%$ & $\mathbf{n}$ & $\%$ \\
\hline Anorexia & 20 & 29.4 & 46 & 67.6 & 2 & 2.9 \\
\hline Arthralgia & 37 & 54.4 & 28 & 41.2 & 3 & 4.4 \\
\hline Headache & 60 & 88.2 & 7 & 10.3 & 1 & 1.5 \\
\hline Abdominal pain & 35 & 51.5 & 30 & 44.1 & 3 & 4.4 \\
\hline Severe pain behind the eyes & 34 & 50.0 & 31 & 45.6 & 3 & 4.4 \\
\hline Fever & 64 & 94.1 & 3 & 4.4 & 1 & 1.5 \\
\hline Palpable liver & 9 & 13.2 & 54 & 79.4 & 5 & 7.4 \\
\hline Asthenia & 36 & 52.9 & 31 & 45.6 & 1 & 1.5 \\
\hline Hypotension & 9 & 13.2 & 55 & 80.9 & 4 & 5.9 \\
\hline Myalgia & 60 & 88.2 & 7 & 10.3 & 1 & 1.5 \\
\hline Nausea/vomiting & 47 & 69.1 & 20 & 29.4 & 1 & 1.5 \\
\hline Rash & 35 & 51.5 & 31 & 45.6 & 2 & 2.9 \\
\hline Dizziness & 22 & 32.4 & 42 & 61.8 & 4 & 5.9 \\
\hline
\end{tabular}

Note: The patients could present some or all the signs/symptoms.

TABLE 2 - Percentage of patients admitted at The Day-Hospital Esterina Corsini from January to April 2007 according to dengue clinic forms and biochemical change examinations.

\begin{tabular}{|c|c|c|c|c|c|c|c|}
\hline \multirow[b]{3}{*}{ Change examinations } & \multicolumn{6}{|c|}{ Clinic form } & \multirow[b]{3}{*}{$\mathbf{P}$} \\
\hline & \multicolumn{2}{|c|}{$\operatorname{CD}(n=56)$} & \multicolumn{2}{|c|}{ HD I $(n=6)$} & \multicolumn{2}{|c|}{ HD II $(n=6)$} & \\
\hline & $\mathbf{n}$ & $\%$ & $\mathbf{n}$ & $\%$ & $\mathbf{n}$ & $\%$ & \\
\hline AST & 45 & 80.3 & 6 & 100.0 & 6 & 100.0 & 0.25 \\
\hline ALT & 39 & 69.6 & 5 & 83.3 & 6 & 100.0 & 0.24 \\
\hline GGT & 24 & 42.8 & 3 & 50.0 & 5 & 83.3 & 0.17 \\
\hline $\mathrm{AP}$ & 15 & 26.7 & 1 & 16.6 & 2 & 33.3 & 0.80 \\
\hline TP & 27 & 48.2 & 3 & 50.0 & 4 & 66.6 & 0.69 \\
\hline ALB & 17 & 30.3 & 3 & 50.0 & 4 & 66.6 & 0.15 \\
\hline
\end{tabular}

CD: classic dengue; HD I: hemorrhagic dengue grade I; HD II: hemorrhagic dengue grade II; AST: aspartate aminotransferase; ALT: alanine aminotransferase; GGT: gamma glutamyl transferase; AP: alkaline phosphatase; TP: total protein; ALB: albumin.

above-normal values for ALT. The AST values of the patients ranged between 22.00 and 907.00 , with an average value of $164.63 \pm 178.59$ (median=96.00). The ALT values ranged between 25.00 and 867.00 , with an average value of $166.07 \pm 158.31$ (median=105.00).

For GGT, $47 \%(32 / 68)$ of the patients reached values above normal, and for AP, $26.5 \%(18 / 68)$ had values above normal. ALB values were observed below the reference value in $35.3 \%(24 / 68)$ of the patients, while TP values were below normal in 50\% (34/68) of the patients.

Patients with classic dengue syndrome $(n=56)$ showed alterations in liver function, as measured by AST and ALT. In this group, $83.3 \%$ and $69.6 \%$ of the patients showed altered levels of AST and ALT, respectively. In the hemorrhagic dengue grade I group $(n=6), 100 \%$ and $83.3 \%$ of the patients showed altered levels of AST and ALT, respectively. In patients with hemorrhagic dengue grade II $(n=6)$, there were elevations for both AST and ALT (Table 2).

The AST and ALT dosage on patients with classic dengue and those who had hemorrhagic dengue (Table 3).

There was a significant linear correlation between AST dosage and patient age; however, it was weak (Pearson linear correlation test, $\left.\mathrm{p}=0.02, \mathrm{r}=0.29, \mathrm{r}^{2}=0.08\right)$. The same was observed between 
TABLE 3 - AST e ALT dosage presented on an average \pm deviation average pattern, according to dengue clinic forms on patients of The Day-Hospital Esterina Corsini, from January to April 2007.

\begin{tabular}{lcc}
\hline Variable & AST & ALT \\
\hline Dengue clinic form & & \\
$\quad$ classic & $147.46 \pm 185.28$ & $152.80 \pm 163.48$ \\
hemorrhagic I & $236.00 \pm 142.27$ & $259.83 \pm 126.11$ \\
hemorrhagic II & $253.50 \pm 103.16$ & $196.17 \pm 111.10$ \\
$p^{*}$ value & 0.007 significance & 0.046 significance \\
& HD II $>$ CD & \\
\hline
\end{tabular}

Note: $p^{*}$ value: Kruskal-Wallis test followed by Dunn post-test (clinic form). AST: aspartate aminotransferase; ALT: alanine aminotransferase; CD: classic dengue; HD II: hemorrhagic dengue grade II.

ALT dosage and age (Pearson linear correlation test, $\mathrm{p}=0.03, \mathrm{r}=0.26$, $\mathrm{r} 2=0.07)$. On the other hand, there was a strong linear correlation between AST and ALT (Pearson linear correlation test, $\mathrm{p}<0.001$, $\left.\mathrm{r}=0.84, \mathrm{r}^{2}=0.70\right)$ (Figure 1).

Correlation analysis was performed between dengue clinical forms with AST and ALT changes. Generally, there was significant difference between the types of dengue in relation with AST dosage (Kruskal-Wallis test, $\mathrm{p}=0.007$ ). The AST dosage on patients with dengue type II was higher than the one observed on patients with classic dengue (A-D) (post-Dunn test, $\mathrm{p}<0.05$ ). The ALT dosage on patients with classic dengue (A-D) was 152.80 \pm 163.48 . Among those with dengue type I, it was $259.83 \pm 126.11$, and it was $196.17 \pm 111.10$ among those with dengue type II. We observed a significant difference between the types of dengue in relation with ALT dosage (Kruskal-Wallis, $\mathrm{p}=0.046$ ), but no difference was observed between them on the multiple comparison test (post-test Dunn, $\mathrm{p}>0.05$ ) (Figure 2).

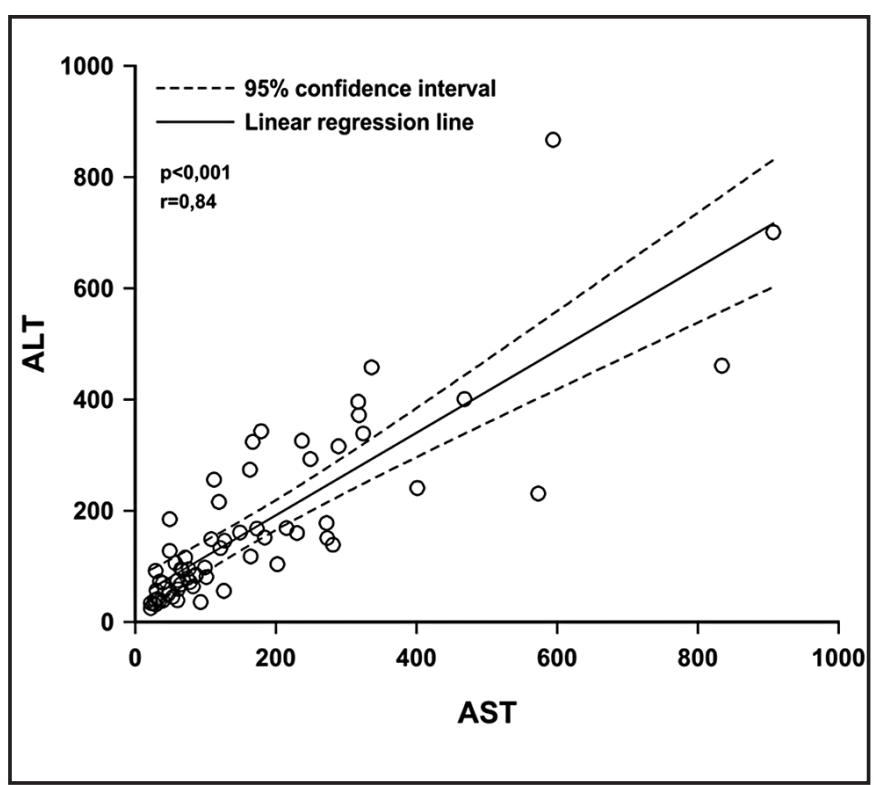

FIGURE 1 - Linear correlation between AST and ALT.

Each symbol (circle) represents the AST and ALT dosage for a single patient (Pearson linear correlation test).

AST: aspartate aminotransferase, ALT: alanine aminotransferase.

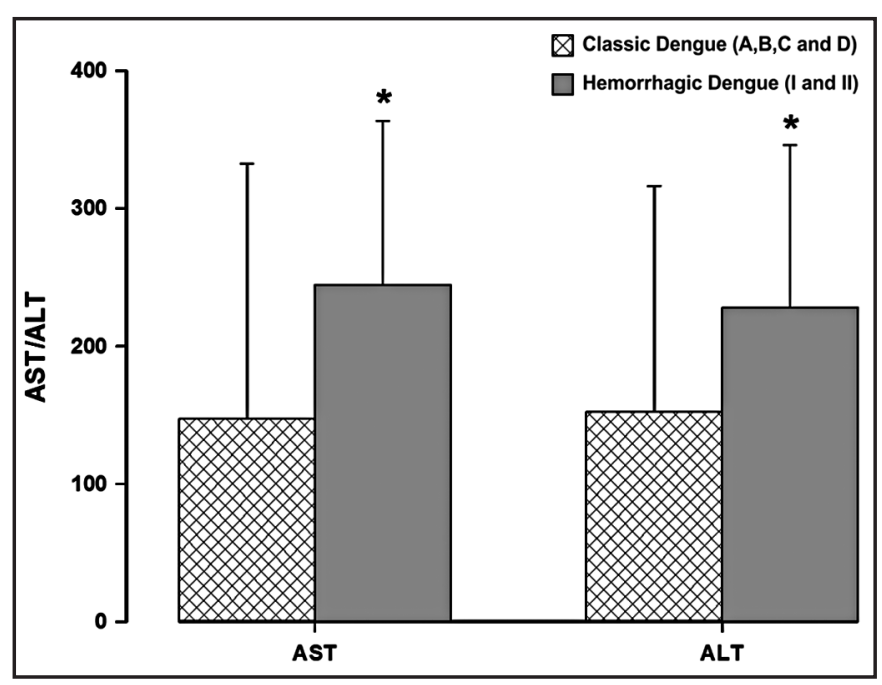

FIGURE 2 - AST and ALT dosage according to dengue clinical form.

The columns represent the average values, and the bars represent the standard deviation.

*Significant difference as compared with the classical form of dengue (Mann-Whitney test; AST: $\mathrm{p}=0.002$, ALT: $\mathrm{p}=0.0014)$.

AST: aspartate aminotransferase, ALT: alanine aminotransferase.

\section{DISCUSSION}

In relation with the clinical manifestation investigation, which could be associated with hepatic function disorders (nausea and vomiting, abdominal pain and hepatomegaly), there were no significant differences among those patients with altered enzymes (AST and ALT) and those who had enzyme dosage within the normal range. These results agree with those observed in other studies ${ }^{1,4,11-13}$.

Regarding the changes in the hepatic function markers, similar values were observed as to that of the other authors' in terms of clinical and epidemiological importance, although there were no statistically significant results ${ }^{8,14-16}$. Both proteins and enzymes, GGT and AP, are scarcely reported on studies relating dengue and hepatic alterations in Brazil. Among those authors cited, only Uehara et al., in 2006, described changes of $40 \%(8 / 20)$ for GGT, $18 \%$ (4/22) on alkaline phosphatase, $30.3 \%(10 / 33)$ on total protein, and $48.4 \%(16 / 33)$ of dosage alteration on serum albumin on a study of 41 patients with hemorrhagic dengue. In our study, these values were similar to those found by the author.

As there has been no significant difference among patients who took or not took potentially hepatotoxic drugs, in relation to aminotransferase elevations, it is possible that these increases have occurred due to dengue infection. The transaminase level may remain normal or elevated regardless of the medication.

The same situation was observed on patients with or without chronic disease. There was no significant relationship between the presence and absence of the disease and the elevation and normality of the transaminase levels.

Many results in this work do not have statistical significance, and many others are justified by the fact that there are three main factors that determine the differences between the samples. The sample size, the size differences among them, and the variability between individual observations of each sample are big problems at the moment in statistical calculations. In our case, we can observe a high variability of AST and ALT, leading to a very large standard deviation and, thus, statistically insignificant results within the confidence interval when compared with clinical proposals. 
The number of the studied patients was relatively low for this type of research, but they strictly followed the proposed criteria for inclusion and exclusion. At the beginning of the proposed research, there were 513 patients, in which 445 were excluded because they did not fulfill the inclusion criteria.

Liver is one of the target organs of dengue virus, and it can be diagnosed hepatomegaly and an increased hepatic protein in serum after infection ${ }^{14}$, therefore, by the range release of inflammatory mediators such as cytokines, which can both protect and damage the body according to individual variations or numbers of infections ${ }^{17}$ These are able to perform their actions by acting on specific receptors present in the membranes of the target cells. The receptor binding is made with high specificity on the extracellular portion, from which there is an intracellular signaling involving proteins of the hepatocyte cytosolic portion ${ }^{18}$.

Several studies have demonstrated that the macrophage migration inhibitory factor (MIF) cytokine has an important role as mediator in inflammatory case $\mathrm{e}^{19}$. This was first described as a lymphokine released from activated $\mathrm{T}$ cells, after finding out that it was responsible for the random migration inhibition of macrophages to the injury-hit site. Thus, these cells started to be addressed in an orderly manner under the MIF guidance. The alpha tumor necrosis factor (TNF), a cytokine that is capable of inducing the production of inflammatory mediators in the local and distant organs, promoting a neutrophil recruitment to the injured areas ${ }^{20}$, has already shown an important role in the unchaining of the inflammatory response induced by dengue virus infection in models with testing animal ${ }^{12}$. Active cells of the immune system are also targets of dengue virus infection; such cells include dendritic cells, natural killer cells (NK), T and B lymphocytes, macrophages, and monocytes.

The high percentage of cases with alterations on hepatic enzymes found in this study highlights the importance of hepatic appraisal on patients with dengue and hemorrhagic dengue. However, we still have much to understand on the interrelationships between DENV and liver. The DENV action in the hepatic cell and its evolution with the illness on previously healthy patients and those with chronic diseases not related to the liver are issues that need to be elucidated in future studies.

The need for a pre-established protocol in conducting this kind of studies is justified once more. On attending patients with suspected dengue, a standardized list of examinations must be requested.

\section{CONFLICT OF INTEREST}

The authors declare that there is no conflict of interest.

\section{REFERENCES}

1. Chang GJ. Molecular biology of dengue viruses. In: Gubler DJ, Kuno G, editors. Dengue and dengue haemorrhagic fever. Cambridge: CAB International; 1997.p. $175-1798$

2. Gubler DJ. The arboviruses: ecology and epidemiology. Flórida (USA): Boca Raton; 1988

3. Hawley WA. The biology of Aedes albopictus. J Am Mosq Control Assoc 1988; 1:1-39.

4. Rai KS. Aedes Albopictus in the Americas. Annu Rev Entomol 1991; 36:459-484

5. Guzmán MG, Kourí G. Dengue: an update. Lancet Infect Dis 2002; 2:33-42.

6. Halstead SB. Dengue. Curr Opin Infect Dis 2002; 15:471-476.

7. Hawley WA. The biology of Aedes albopictus. J Am Mosq Control Assoc $1988 ; 1: 1-39$.
8. Cunha RV, Marques Filho VS, Aguiar JIA, Paniago AMM, Lindenberg ASC, Hans Filho G, et al. Dengue Hemorrágico em Campo Grande, MS: Relato do primeiro caso diagnosticado. Rev Soc Bras Med Trop 1996; 29 (suppl I): 57.

9. Ministério da Saúde. Programa Nacional de Controle da Dengue. Brasília: Fundação Nacional da Saúde; 2002.

10. Díaz SV, Martínez MP, Saent-Félix FG. Hepatitis reactive poor virus del dengue hemorrágico. Rev Cubana Med Trop 2001; 53:28-31.

11. Nogueira RMR, Filippis AM, Coelho JM, Sequeira PC, Schatzmayr HG, Paiva FG, et al. Dengue virus infection of the central nervous system (CNS): A case report from Brazil. Southeast Asian J Trop Med Public Health 2002; 33:68-71.

12. Atrasheuskaya A, Petzelbauer P, Fredeking TM, Ignatyev G. Anti-TNF antibody treatment reduces mortality in experimental dengue virus infection. FEMS Immunol Med Microbiol 2003; 35:33-42.

13. Souza LJ, Nogueira RMR, Soares LC, Soares CED, Ribas BF, Alves FP, et al. The impact of dengue on liver function as evaluated by aminotransferase levels. Braz J Infect Dis 2007; 11:407-410.

14. Jessie K, Fong MY, Devi S, Lam SK, Wong KT. Localization of dengue virus in naturally infected human tissues, by immunohistochemistry and in situ hybridization. J Infect Dis 2004; 189:1411-1418.

15. Ministério da Saúde. Dengue no Brasil Informe Epidemiológico. Semana 15 Brasília: Secretaria de Estado de Saúde. Sistema de Vigilância em Saúde. 2009 [cited 2009 June 03]. Available from www.saude.gov.br/.

16. Nguyen TL, Nguyen TH, Tieu NT. The impact of dengue haemorrhagic fever on liver function. Res Virol 1997; 148:273-277.

17. Lei HY, Yeh TM, Liu HS, Lin YS, Chen SH, Liu CC. Immunopathogenesis of dengue virus infection. J Biomed Sci 2001; 8:377-388.

18. Hanada T, Yoshimura A. Regulation of cytokine signaling and inflammation Cytokine Growth Factor Rev 2002; 13:413-421.

19. Radstake TR, Sweep FC, Welsing P, Franke B, Vermeulen SH, Geurts-Moespot A et al. Correlation of rheumatoid arthritis severity with the genetic functional variants and circulating levels of macrophage migration inhibitory factor. Arthritis Rheum 2005; 52: 3020-3029.

20. Souza DG, Cara DC, Cassali GD, Coutinho SF, Silveira MR, Andrade SP, et al Effects of the PAF receptor antagonist UK74505 on local and remote reperfusion injuries following ischaemia of the superior mesenteric artery in the rat. Br J Pharmacol 2000; 131:1800-1808. 